\title{
China's role in the next phase of the energy transition: contributions to global niche formation in the Concentrated Solar Power sector
}

Jorrit Gosens ${ }^{1,2,}{ }^{,}$, Christian Binz ${ }^{3}$, Rasmus Lema ${ }^{1}$

1) Department of Business and Management, Aalborg University, Frederikskaj 10B, 2450 Copenhagen SV, Denmark

2) Sino-Danish Center for Education and Research (SDC), Niels Jensens Vej 2, 8000 Aarhus C, Denmark

3) Eawag - Swiss Federal Institute of Aquatic Science \& Technology, Überlandstrasse 133, 8600 Dübendorf, Switzerland

*) Corresponding author; jorrit@business.aau.dk

\begin{abstract}
The role that emerging economies, and China in particular, play in the global energy transition appears to be transforming. Transition literature to date characterizes the formation of cleantech sectors in emerging economies as being heavily dependent on foreign inputs of knowledge and other key resources. This article argues that in the, currently unfolding, next phase of the global energy transition, Chinese actors may play a more central role in global niche development for high-tech industries, including in constructing innovative and effective socio-technical configurations. This argument is illustrated with a case study of the Chinese Concentrated Solar Power industry, which is found to have developed largely independently of foreign resources. The case is used to highlight a number of specificities of the Chinese environment that set it apart from niche formation environments in OECD countries, and may allow China to open up technological trajectories unlikely to develop in those OECD countries.
\end{abstract}

Keywords: Concentrated Solar Power; China; Technological Innovation Systems; System building resources; Industry formation

This document is the accepted manuscript version of the following article: Gosens, J., Binz, C., \& Lema, R. (2020). China's role in the next phase of the energy transition: contributions to global niche formation in the concentrated Solar Power sector. Environmental Innovation and Societal Transitions, 34, 61-75. https://doi.org/10.1016/j.eist.2019.12.004

This manuscript version is made available under the CC-BY-NC-ND 4.0 1icense http://creativecommons.org/1icenses/by-nc-nd/4.0/ 


\section{Introduction}

Preventing dangerous levels of climate change requires deep decarbonization of global systems for the production and consumption of energy. An ongoing transition to cleaner sources is particularly visible in electricity production, where onshore wind and solar PV in particular are starting to attain substantial market shares in a number of countries. Transition scholars have argued that transition dynamics in the energy sector are now entering a new phase in which, amongst others, the diffusion of renewables is accelerating, support policies are re-aligned from R\&D and price support towards system integration and complementary technologies, and renewables are starting to push out rather than add to conventional sources of power generation (Markard, 2018; Smil, 2016). The foundational concepts of the field would accordingly have to be adapted or reformulated to explain these new dynamics. This paper embraces this argument, but highlights an area that has thus far mostly been overlooked in the debate about the next phase of transition concepts: the increasingly central, and potentially transformative, role that actors in emerging economies could have.

In the first phase of the global energy transition, early stage $R \& D$, as well as market and industry formation around renewable energy technologies was largely concentrated in advanced economies. Only in later stages did renewable energy industries like wind and solar PV spread to emerging and developing economy countries (Lema and Lema, 2012; Quitzow, 2015). China is a case in point, having grown from a marginal role in renewable energy industries around the year 2000, to the worlds' largest market and equipment manufacturer for wind and PV in recent years.

Much scholarly attention has been focused on the conditions that enabled this shift of manufacturing industries towards China and other emerging economies such as India, South Korea, Brazil, etc. (Binz and Anadon, 2018; de la Tour et al., 2011; Fu and Zhang, 2011; Gosens and Lu, 2013; Lema and Lema, 2012; Lewis, 2007; Quitzow, 2015). These studies have in large part re-iterated conclusions from literatures on National Innovation Systems or on catchingup. They have pointed out that China and other emerging economy countries started to gain market shares in the wind and solar PV industry, when these industries had entered a relatively mature stage in their global life-cycle, i.e., when dominant designs had emerged, and substantial experience and industry leadership had been built up elsewhere (Malerba and Nelson, 2011; Mathews, 2006; Shin, 1996). These studies have further stressed the importance of domestic capability formation through the absorption of foreign technology 
and experience (Abramovitz, 1986; Ernst and Kim, 2002; Gereffi et al., 2005; Lundvall, 1992; Perez and Soete, 1988).

The next phase of the global energy transition is expected to see accelerated deployment of wind and PV, which are relatively mature technologies by now (Markard, 2018). A new generation of renewable energy technologies, including Concentrated Solar Power (CSP), tidal \& wave power, enhanced geothermal, and thin film, perovskite and organic PV, are still in earlier stages of development, but may see strong future growth, and come to support or compete with current mainstream renewables (Hussain et al., 2017). Should history repeat itself, development and deployment of these technologies would remain limited to advanced economy countries for the foreseeable future, and shift towards emerging economies only after a lengthy process of technological maturation.

There are, however, indications that this is not what is happening in a number of nextgeneration renewables, and with CSP in particular. This sector is currently in its formative stage, with only small niche markets in a limited number of countries, and research programs in place to tackle fundamental engineering challenges even in advanced economy countries. Nevertheless, a demonstration program is underway in China, with support for 20 CSP projects with a total capacity of 1,349 MW, making China one of the largest current CSP markets (NEA, 2016; SolarPACES/NREL, 2018).

This article will highlight the divergence from traditional catch-up development in the Chinese CSP sector by analysing the relative importance of domestic and foreign elements in its early stage CSP industry formation. Similar to recent analyses on transnational innovation dynamics in emergent cleantech sectors (Andersson et al., 2018; Binz and Anadon, 2018), we will trace the origin of four industrial path formation resources (knowledge, market demand, investment, and legitimacy). This is done through a review of Chinese government policy and industry reports, the creation of a database of actors involved in pilot and demonstration projects, and a series of interviews with Chinese CSP experts in academia, industry, and government.

Our findings show that Chinese CSP sector development has occurred largely independent from foreign innovation system resources. Technological development, as well as pilot and demonstration activities are strongly rooted in domestic knowledge bases and technological capabilities of local firms. The bulk of the project developers, design institutes, EPC contractors, equipment manufacturers and financiers are domestic. Domestic markets are being actively created and dominated by Chinese developers and equipment 
manufacturers, and these have started to make inroads into foreign markets. Rather than depending on foreign standards or inclusion in global supplier networks, Chinese actors are helping set global standards and take lead firm roles in developing supplier networks.

These findings suggest that global development patterns of innovative activity for the next generation of renewable energy technologies may see a decidedly different role for emerging economies. China in particular appears to have an environment suitable for early stage industrial path development, benefitting from a specific combination of policy-induced experimentation, bottom-up entrepreneurship, and risk acceptance levels by key investors that exceed Western standards (cf. Gosens et al., 2018; Tyfield, 2018; Tyfield et al., 2015). Discussions on the concept of the next phase of the global energy transition should arguably include attention to shifting geographical patterns in the development of next generation renewables technologies and their industries.

\section{Theory and method}

Emerging or developing economies are typically latecomers in newly emerging technological fields; an issue intimately connected with their lagging economic development status (Abramovitz, 1986; Lundvall, 1992). Although this means that domestic innovation system formation lags behind the global forefront, it also provides a 'latecomer advantage' to rapid industry formation, through the absorption of up-to-date technology from abroad (Gerschenkron, 1962; Mathews, 2002).

Analysts studying the recent development of wind, PV, and other renewable energy industries in emerging and developing economies have therefore often focused on the ways in which these countries managed to access and utilize foreign technology (de la Tour et al., 2011; Fu and Zhang, 2011; Gosens and Lu, 2013; Lema and Lema, 2012; Lewis, 2007; Quitzow, 2015). One strand of inquiry has looked into the various possible (organizational) arrangements for accessing foreign technology, such as government assisted transfer programs, licensing of designs, mergers and acquisitions, etc. (Lema and Lema, 2012; Lewis, 2007). Another strand has analysed the shift from dependency on global sources towards more strongly domestically rooted innovation systems in other elements, such as human resources, finance, standard setting, etc. (Gosens and Lu, 2013; Lewis, 2010). By extension, some analysts have assessed not only how emerging economies have managed to reduce their dependency on foreign inputs, but also how they have come to contribute to innovation systems development outside of their domestic context (Binz and Anadon, 2018; Gosens and Lu, 2013; Quitzow, 2015). 
Other transition scholars have argued against the preoccupation with technological capabilities and industrial sophistication that is typical in the above-mentioned literature, and stress that in a number of cases, the key transformative impetus from Chinese actors rather stems from radically novel service solutions, or shifts in user preferences and practices (Smith and Ely, 2015; Tyfield, 2018; Tyfield et al., 2015). Put differently, industrial path development for clean-tech in China is not about knowledge leadership alone, but increasingly also about mobilizing financial investment, constructing new markets and user practices, as well as technology legitimation dynamics (Yap et al., 2019; Yap and Truffer, 2019). The resulting innovative socio-technical arrangements that emerge in fields as diverse as urban mobility, IT services or renewable energy sectors may become highly relevant for wider global decarbonization trajectories (Tyfield, 2018; Tyfield et al., 2015).

China's recent activities at building a Concentrated Solar Power (CSP) sector present an interesting case for follow-up research along these same lines, as 1) the global CSP sector is decidedly less mature than the wind or PV sectors were when China entered these sectors, meaning that there is less scope for traditional learning or technology transfer mechanisms, and 2) China's generic innovative capabilities vis-à-vis global competitors have substantially improved as well. The current analysis therefore sets out to analyse the innovation system formation of China's CSP sector, with a particular focus on the level of dependency on foreign inputs, as well as to contributions to innovation systems development outside of the Chinese context, and comment on differences with earlier experiences in other renewable energy sectors.

The framework for this analysis draws on work on multi-scalar interaction in industrial path development (Andersson et al., 2018; Binz et al., 2016; Binz and Anadon, 2018), and work on trans-national linkages in Technological Innovation Systems (Binz and Truffer, 2017; Gosens et al., 2015; Gosens and Lu, 2013; Hansen and Nygaard, 2013; Quitzow, 2015; Wieczorek et al., 2015a). Both frameworks are particularly concerned with early phase industry formation, conceive of technological development as interrelated with its social and economic environment, and have explicit attention for the inter-connectedness of domestic and foreign innovation system formation processes.

The work on multi-scalar interaction in industrial path development argues that there are four key system resources, namely knowledge, market demand, finance, and legitimacy (Table 1), required for any industrial path to emerge (Binz and Truffer, 2017). If a certain 
resource is missing, local actors will have to find ways to either mobilize it locally, or supplement it from foreign sources (Binz et al., 2016; Schmidt and Huenteler, 2016). The location where new industries form, and the speed with which they may shift from one location to another then critically depend on the availability, and transferability of these key system resources (Andersson et al., 2018; Binz et al., 2016; Binz and Anadon, 2018). This literature provides a generic conceptual framework on the relevant system resource formation processes and their multi-scalar coupling in 'global innovation systems' (Binz and Truffer, 2017), but the concrete transnational linkages or mechanisms of transfer of resources remain somewhat underspecified.

The work on the trans-national linkages in TIS has similarly identified that domestic TIS formation in latecomer economies may be bolstered by interaction with foreign TIS. It can complement the literature on multi-scalar interaction in industrial path development as it offers clear lists of various trans-national structures and how they connect different domestic TIS with, for example, border-crossing flows of knowledge embedded in patents or design licenses, foreign investment, access to international markets, or international personnel mobility (Gosens et al., 2015; Gosens and Lu, 2013; Hansen and Nygaard, 2013; Quitzow, 2015; Wieczorek et al., 2015b, 2015a). Linkages may also exist in more intangible exchange processes between various national TIS, for example with implementation of foreign policy templates (i.e. feed-in-tariff systems, bus rapid transfer policies) with limited adaptation to local contexts (Quitzow, 2015; Sengers and Raven, 2015), collaboration in large international $R \& D$ and experimentation projects (Wieczorek et al., 2015b), or the use of globally recognized quality standards and certification schemes (Zhang and White, 2016).

In the current analysis, we combine the concepts of resources for domestic industry formation with the concrete mechanisms for exchange between various national TISs (Table 1), in doing so providing conceptual clarity on what is exchanged between domestic and foreign innovation systems, and how such exchanges may occur. This framework will be used to analyse activities to mobilize local resources, and gauge both incoming and outgoing transfers of system resources between domestic and global resource pools. The level of dependency on, and contribution to, global resource pools, will simultaneously be used to gauge the relative strength of the domestic vis-à-vis foreign innovation systems for CSP technologies. 
Table 1. Key resources for industrial path formation and mechanisms for exchanges between domestic and global resource pools

\begin{tabular}{|c|c|c|}
\hline System resource & $\begin{array}{l}\text { Mechanisms for local mobilization of } \\
\text { system resources }\end{array}$ & $\begin{array}{l}\text { Mechanisms for exchanges between domestic } \\
\text { and global resource pools }\end{array}$ \\
\hline Knowledge & $\begin{array}{l}\text { Activities that create new } \\
\text { technological knowledge and related } \\
\text { competencies, e.g., through learning } \\
\text { by searching, doing, using, or } \\
\text { interacting }\end{array}$ & 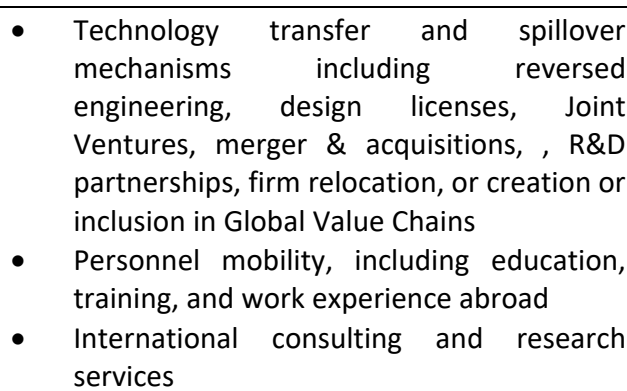 \\
\hline Market demand & $\begin{array}{l}\text { Activities by entrepreneurs, user } \\
\text { groups, or government intervention } \\
\text { that contribute to the creation of } \\
\text { (protected) market space or new } \\
\text { market segments }\end{array}$ & $\begin{array}{l}\text { - Demand in domestic and export markets as } \\
\text { mediated by regulations, including tariff, } \\
\text { import restrictions, domestic content } \\
\text { requirements, preferential government } \\
\text { procurement, export credits, etc. }\end{array}$ \\
\hline $\begin{array}{l}\text { Financial } \\
\text { investment }\end{array}$ & $\begin{array}{l}\text { Activities related to the mobilization } \\
\text { and allocation of basic financial inputs } \\
\text { such as bank loans, venture capital or } \\
\text { angel investment require for the } \\
\text { continuation and growth of research } \\
\text { and business activities }\end{array}$ & $\begin{array}{l}\text { - Official development aid and other grants } \\
\text { - Institutional lending from development } \\
\text { banks or other bi/multi-lateral lending } \\
\text { - Specific international support such as the } \\
\text { Clean Development Mechanism or the } \\
\text { Green Climate Fund } \\
\text { - Foreign direct investment \& Outgoing direct } \\
\text { investment } \\
\text { - } \quad \text { Public offerings or private equity in foreign } \\
\text { capital markets } \\
\text { - } \quad \text { Export credit \& export credit insurance }\end{array}$ \\
\hline Legitimacy & $\begin{array}{l}\text { Activities that embed a new } \\
\text { technology within relevant } \\
\text { (normative, regulative, or cognitive) } \\
\text { institutional structures or adapt the } \\
\text { institutional environment to the } \\
\text { needs of the technology }\end{array}$ & $\begin{array}{l}\text { - Involvement in global technical standard } \\
\text { setting committees \& adherence to global } \\
\text { standards } \\
\text { - Exchange of best practices and other } \\
\text { insights in global industry platforms \& policy } \\
\text { exchange platforms } \\
\text { - International certification services }\end{array}$ \\
\hline
\end{tabular}

Note: resource categorization and mechanisms for mobilization from (Binz et al., 2016; Binz and Anadon, 2018); exchange mechanisms based on (Gosens et al., 2015; Quitzow, 2015). 


\subsection{Method, case selection, and data collection}

The paper applies an in-depth single case study design, focusing on the Chinese CSP sector, based on an extreme case sampling rationale (Teddlie and Yu, 2007). The limited global sector formation means that there is little potential for learning or catch-up mechanisms, which are typically used to upgrade domestic capabilities in emerging economy countries. Existing explanations on industrial path development would similarly consider that emerging economies are particularly poorly equipped to develop a competitive CSP industry in this stage of its global sector development. CSP is arguably a 'complex products and systems' type of technology, which depends on high-level engineering skills, and the capability of pioneering actors to combine a broad set of previously unrelated knowledge bases. Further, the relative novelty of the technology means that its role or purpose in energy markets, and legitimation for its development and utilization are not fully settled yet. Given these interrelated challenges, existing theorizing would assume advanced economy countries with better suited related industrial capabilities, and innovation system structures that foster their creative recombination, are in a better structural position to develop these industry paths.

Data collection on global sector status was done through a review of journal articles and industry reports, and global CSP project databases (Lilliestam et al., 2017; SolarPACES/NREL, 2018). Information on Chinese projects was collected from annual industry status reports by the Chinese National Solar Thermal Alliance, and Chinese CSP industry news sites, mostly from CNSTE, CSP Focus, and CSP Plaza. These sites report on project status updates and the results of tenders for components and services. This information was collected in a database of firms, research institutes, etc., that were involved in each of China's CSP projects, in order to identify key industry players. A summary of this data is provided in the supplementary material. This was supplemented with information from interviews with 31 experts from 24 different organizations, held in November 2018 and May 2019 in China. These were with either Chinese organizations or foreign firms active in China, including developer companies, equipment manufacturers, policy making, industry alliance groups, and engineering departments of key universities (details in Appendix A). Most interviewees were internationally active and so had no issue to hold the interview in English. In a few exceptions, the interviews were held in Chinese; the first author of this article speaks Chinese, whilst transcription of Chinese interviews was outsourced to native speakers to ensure there had not been any misunderstandings. These interviews focused on system building activities by these actors, the geographical origin of system building resources, and the mechanisms through which these were created or accessed. 


\section{Sector overview}

Although there is a rich literature on CSP technologies relating to engineering and economic aspects (Chaanaoui et al., 2016; Lilliestam et al., 2017; Villarini et al., 2011), it has so far received very little attention in the literature on innovation or sustainability transitions, with a small number of exceptions ( $\mathrm{Hu}$ and Wu, 2013; Lilliestam et al., 2018; Vieira de Souza and Gilmanova Cavalcante, 2017; Wang et al., 2017). Here, we first help fill some of this gap by providing a description of Concentrated Solar Power technologies (section 3.1), and a descriptive overview of sector developments globally (section 3.2), and in China (section 3.3).

\subsection{Description of Concentrated Solar Power technologies}

Concentrated Solar Power (CSP) is a set of technologies that use large surface areas of reflectors (mirrors) to focus sunlight onto a much smaller receiver area, where heat is collected. This heat can be utilized directly in industrial processes or in space heating, or to generate electrical power.

The technology can be considered to still be in a formative phase as several different overall designs for CSP plants are still being considered (figure 1) and government funded research is underway to develop the technology "to pre-commercial or commercial level" (EC, 2018; U.S. DOE, 2018). The parabolic trough design is by far the most conventional, but the central tower design is increasingly frequently used in recent projects, and in those under construction (SolarPACES/NREL, 2018). The other designs included in Figure 1 are less common but are all used in a small number of operational (pilot) plants.

Plants can be further differentiated by the type of heat-transfer fluid (HTF) used. Different HTF allow for different operating temperatures, with higher temperatures improving plant efficiency. The most conventional HTF is thermal oil, which allows operating temperature of up to circa $350^{\circ} \mathrm{C}$. A smaller number of plants uses water or steam as the HTF. In recent years, and particularly in projects still under construction, molten salt, which allows operating temperatures of up to $600^{\circ} \mathrm{C}$, is an increasingly common HTF (Author's database, 2018; SolarPACES/NREL, 2018). Molten salt has the added benefit that it can be used for thermal storage at relatively low cost. 


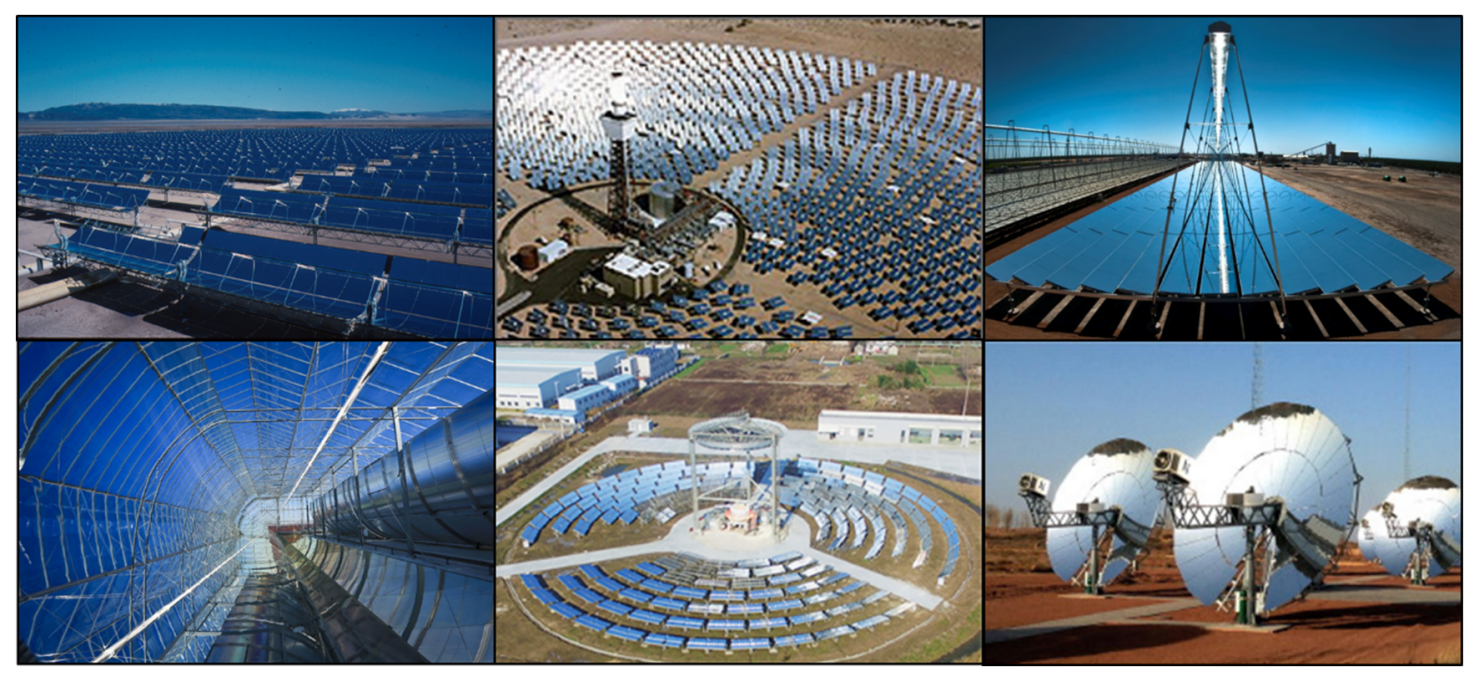

Figure 1. Designs of Concentrated Solar Power plants. Top left: parabolic trough (BLM, 2004); top centre: central tower receiver (Sandia National Laboratories, 2018); top right: linear Fresnel (Laird, 2012); bottom left: Enclosed parabolic trough (Glasspoint Solar, 2014); bottom centre: central beam down tower with ground-level receiver (CNSTE, 2017a); bottom right: Parabolic dish with Sterling engine (Coventry and Andraka, 2017).

\subsection{Global sector developments}

Global operational capacity of CSP plants stood at 5,214 MW by year-end 2017, or roughly $1 \%$ of the global capacity of wind or PV. This was made up of 81 commercial-scale projects, with circa $90 \%$ completed since the year 2010 , and circa $85 \%$ located in just two countries; the US and Spain (Figure 2).

The first utility-scale CSP project was the Solar Energy Generating Systems (SEGS) in California, built in the 1980's. The SEGS consists of 9 phases of $354 \mathrm{MW}$ in total, all parabolic troughs with thermal oil as the HTF, and is still in operation today (SolarPACES/NREL, 2018). After completion of the SEGS, it took a full 17 years before any other CSP project became operational (Figure 2).

In the late 2000's and early 2010's, the global market was almost entirely driven by developments in Spain, where generous support policies were put in place. The first plant to come online in this CSP renaissance was the $10 \mathrm{MW}$ Planta Solar 10 (or PS10) in 2007. The PS10 was developed by the Spanish Abengoa Solar, and was the world's first commercial-scale project that used a central tower design. In 2011, another Spanish developer, Gemasolar, built a $20 \mathrm{MW}$ tower, which was the world's first commercial-scale plant using molten salt. However, the bulk of projects operational by year end 2017 still use parabolic trough design, with thermal oil as the HTF (SolarPACES/NREL, 2018). 
Spanish development of CSP has ceased after strong reduction in Spanish Feed-in tariffs. The stop-and go nature of support measures in the US have made it a difficult market as well, leading to a number of bankruptcies or industry exits of leading equipment manufacturers and developers (Chaanaoui et al., 2016; Hu and Wu, 2013; Martin, 2016). Current growth markets are in the MENA region, Chile, China, and possibly India (Philibert, 2014 see also Figure 2).
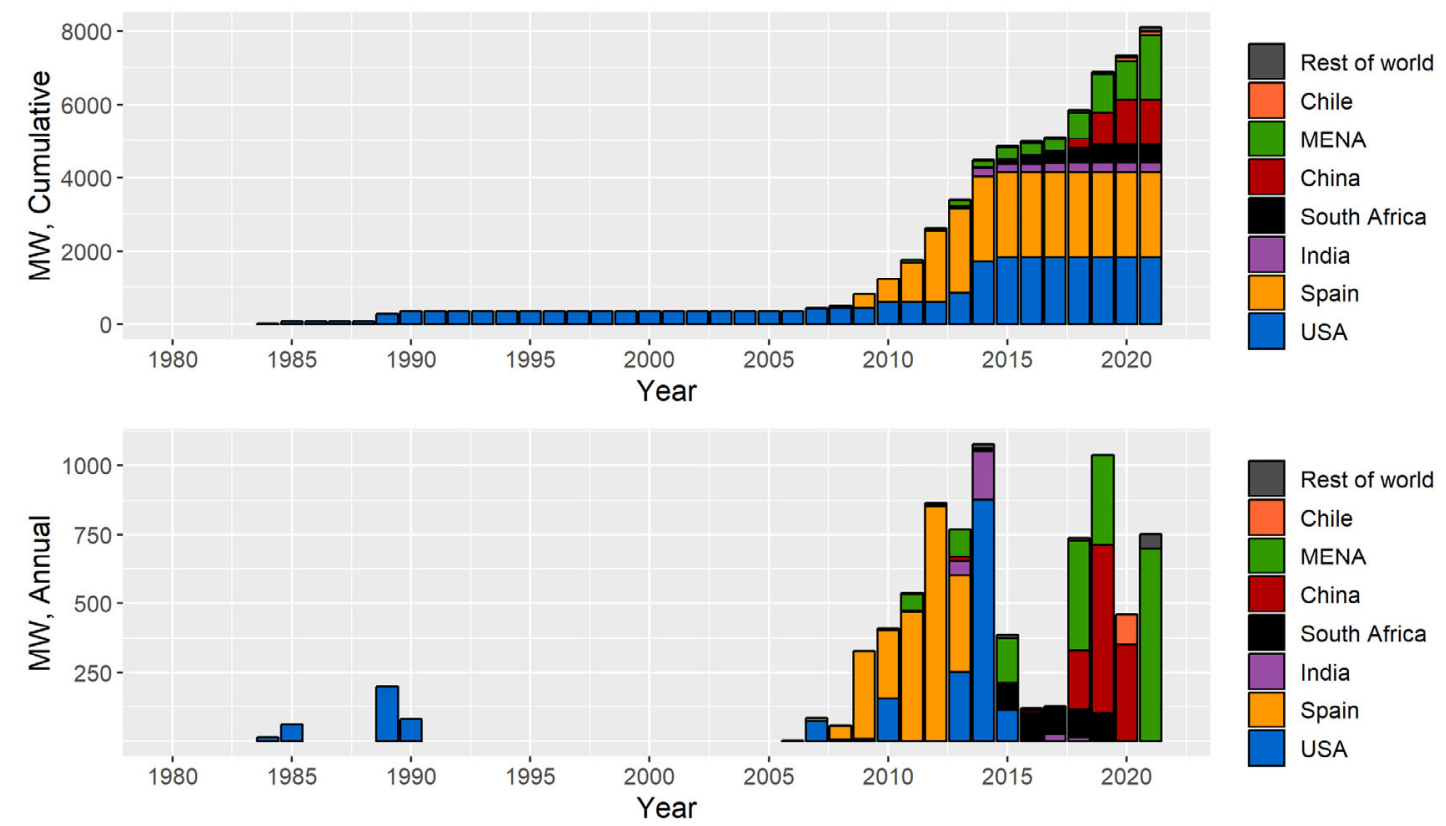

Figure 2. Global CSP installations by country (group), with forecasts for 2019 onwards. Sources: (Lilliestam et al., 2017; SolarPACES/NREL, 2018); for Chinese projects see supplementary material. 


\subsection{Chinese sector developments}

An overview of key developments and lighthouse projects in the Chinese CSP sector, from pilot to utility-scale, is provided in Table 2. Further details on the current batch of utilityscale projects under construction is provided in Table 3. 
Table 2. Historical overview of key developments in China's CSP sector

\begin{tabular}{|c|c|c|}
\hline $\begin{array}{l}\text { Sector } \\
\text { development } \\
\text { stage }\end{array}$ & Period & Description of activities \\
\hline \multirow[t]{5}{*}{$\begin{array}{l}\text { Small scale pilot } \\
\text { activities }\end{array}$} & $\begin{array}{l}1986- \\
1990\end{array}$ & $\begin{array}{l}\text { China's earliest CSP pilot plant was constructed during the } 7^{\text {th }} \text { Five-Year Plan. It } \\
\text { was a } 24 \text { meter parabolic trough, funded by MOST, and carried out by a } \\
\text { consortium of the Institute of Electrical Engineering of the Chinese Academy of } \\
\text { Sciences (IEE-CAS), Tsinghua University, and a domestic equipment } \\
\text { manufacturer }\end{array}$ \\
\hline & 2004 & $\begin{array}{l}\text { Second identifiable pilot project, a } 12 \mathrm{~m} \text { trough project by Himin Solar and IEE- } \\
\text { CAS, in Tongzhou, a suburb of Beijing }\end{array}$ \\
\hline & 2005 & $\begin{array}{l}\text { China's first tower type project, } 70 \mathrm{~kW} \text { pilot project in Jiangning, Jiangsu, by } \\
\text { the Chinese Academy of Engineering, Himin, and IEE-CAS }\end{array}$ \\
\hline & 2009 & $\begin{array}{l}\text { Start of construction of a test-base by China General Nuclear (CGN) in } \\
\text { Delingha. Included a } 1.6 \mathrm{MW} \text { parabolic trough and a } 1.6 \mathrm{MW} \text { linear Fresnel } \\
\text { project, finished in } 2013\end{array}$ \\
\hline & 2010 & $\begin{array}{l}\text { Start of construction of test-base in Yanqing, a suburb in Beijing, by IEE-CAS } \\
\text { and Himin. Initially a } 124 \mathrm{~m} \text { trough project, with a } 1 \mathrm{MW} \text { tower added in } 2012 \text {, } \\
\text { and a } 1 \mathrm{MW} \text { trough added during the } 12^{\text {th }} \text { FYP period (2011-2015) }\end{array}$ \\
\hline \multirow[t]{3}{*}{$\begin{array}{l}\text { Small scale } \\
\text { demonstration }\end{array}$} & 2010 & $\begin{array}{l}\text { SupCon Solar start construction on a project with two } 5 \mathrm{MW} \text { towers, using } \\
\text { water/steam as heat transfer fluid, finishing in } 2012 \text {. One tower was } \\
\text { retrofitted to use molten salt in 2014, enabling heat storage. This was only the } \\
\text { sixth project globally using the central tower design, and the third using } \\
\text { molten salt }\end{array}$ \\
\hline & 2013 & $\begin{array}{l}\text { SunCan is established and starts construction of a } 10 \mathrm{MW} \text { molten salt tower in } \\
\text { Dunhuang, Gansu province in 2014. The project was operational by December } \\
\text { of } 2016\end{array}$ \\
\hline & 2013 & $\begin{array}{l}\text { CGN announces a } 10 \mathrm{MW} \text { tower demonstration project in its experimental } \\
\text { base Delingha, but never started construction }\end{array}$ \\
\hline \multirow[t]{3}{*}{$\begin{array}{l}\text { Plans, but little } \\
\text { more, for } \\
\text { utility-scale } \\
\text { projects }\end{array}$} & 2011 & $\begin{array}{l}\text { NDRC holds a tender for the development of a utility-scale CSP project. Three } \\
\text { projects apply, but the winning bid, for a } 50 \mathrm{MW} \text { trough project in Ordos, by } \\
\text { Datang, was never constructed, likely because its bid of } 0,93 \mathrm{CNY} / \mathrm{kWh} \text { was too } \\
\text { low }\end{array}$ \\
\hline & 2012 & $\begin{array}{l}\text { NDRC approves four utility-scale projects, all four of which are proposed by } \\
\text { SOE power companies. They are the Datang project in Ordos, a } 50 \mathrm{MW} \text { trough } \\
\text { project in Jinta by Huadian, a } 92.5 \mathrm{MW} \text { trough project in Hanas by Hanas } \\
\text { Energy, and a } 50 \mathrm{MW} \text { trough in Delingha by CGN solar. Only the latter gets } \\
\text { built, but only after receiving a FiT in } 2016\end{array}$ \\
\hline & $\begin{array}{l}2012- \\
2016\end{array}$ & $\begin{array}{l}\text { At least another } 61 \text { utility-scale projects }(30+\mathrm{MW}) \text { are announced by } \\
\text { developer firms. None of these is ultimately constructed due to lacking price } \\
\text { support policies }\end{array}$ \\
\hline $\begin{array}{l}\text { Sector take off: } \\
20 \\
\text { 'demonstration' } \\
\text { projects }\end{array}$ & $\begin{array}{l}2016 \text { - } \\
\text { current }\end{array}$ & $\begin{array}{l}\text { In September 2015, the National Energy Administration (NEA) asked for bids to } \\
\text { develop CSP demonstration projects with a minimum scale of } 50 \mathrm{MW} \text {. In } \\
\text { September of 2016, a total of } 20 \text { projects with a combined capacity of 1,350 } \\
\text { MW was selected; see Table } 3 \text { for details. } \\
\text { This list included } 9 \text { towers using molten salt as the HTF, whilst only } 2 \text { such } \\
\text { utility-scale projects were operational worldwide at the time. } \\
\text { It also included } 3 \text { parabolic trough projects using molten salt, which would be } \\
\text { world's first. } \\
\text { It further included } 4 \text { utility-scale Fresnel projects, whilst only a single such } \\
\text { utility-scale project was operational at the time, and including the world's first } \\
\text { Fresnel project using molten salt. }\end{array}$ \\
\hline
\end{tabular}

Sources: (CNSTE, 2013; CSP Plaza, 2015; MOST, 2011; Wang et al., 2017). See further projects details in supplementary material. 
Table 3. The 20 projects in China's first batch of CSP demonstration projects

\begin{tabular}{|c|c|c|c|c|c|c|c|c|}
\hline Developer & MW & Type & HTF & $\begin{array}{l}\text { Storage } \\
\text { length }(\mathrm{h})\end{array}$ & $\begin{array}{l}\text { Storage } \\
\text { medium }\end{array}$ & Province & Key tech supplier \& system integration & Expected \\
\hline Supcon Solar & 50 & Tower & Molten salt & 6 & Molten salt & Qinghai & Supcon Solar & Dec-18 \\
\hline Shouhang IHW & 100 & Tower & Molten salt & 11 & Molten salt & Gansu & SunCan & Dec-18 ${ }^{d}$ \\
\hline $\begin{array}{l}\text { Northwest } \\
\text { Engineering }\end{array}$ & 50 & Tower & Molten salt & 6 & Molten salt & Qinghai & Supcon Solar \& Northwest Engineering & Sep-19d \\
\hline NWEPDI & 50 & Tower & Molten salt & 8 & Molten salt & Xinjiang & Supcon Solar \& NWEPDI & Dec-19 \\
\hline SPIC Huanghe & 135 & Tower & Molten salt & 3.7 & Molten salt & Qinghai & Brightsource (US) $)^{\text {a } \& ~ N W E P D I ~}$ & Uncleare $^{\mathrm{e}}$ \\
\hline Three Gorges & 100 & Tower & Molten salt & 8 & Molten salt & Gansu & SunCan \& Northwest Engineering & Dec-20 \\
\hline Dahua \& IEE-CAS & 50 & Tower & Molten salt & 4 & Molten salt & Hebei & IEE-CAS & $(\text { Dec-19) })^{f}$ \\
\hline Yumen Xinneng & 50 & Tower & Molten salt & 6 & Molten salt & Gansu & Shanghai Parasol \& Jiangsu XinChen & Dec-19 \\
\hline Shouhang $\mathrm{IHW}^{\mathrm{b}}$ & 100 & Tower & Molten salt & 10 & Molten salt & Gansu & SunCan & Oct-20 \\
\hline Royaltech & 50 & Through & Thermal oil & 7 & Molten salt & Gansu & Royaltech & $(\text { Dec-19) })^{f}$ \\
\hline Shenzhen JinFan & 50 & Through & Molten salt & 15 & Molten salt & Gansu & Tianjin Binhai & $($ Dec-19) \\
\hline Rayspower & 50 & Through & Thermal oil & 7 & Molten salt & Gansu & Rayspower & (Jun-19) $^{f}$ \\
\hline CNNC \& Royaltech & 100 & Through & Thermal oil & 4 & Molten salt & Inner Mongolia & CNNC \& Royaltech & Dec-19 \\
\hline CGN Solar & 50 & Through & Thermal oil & 9 & Molten salt & Qinghai & CGN Solar & Sep-18 \\
\hline CECEP & 100 & Through & Thermal oil & 7 & Molten salt & Gansu & Royaltech \& CECEP & Dec-20 \\
\hline Zhongyang Energy & 64 & Through & Molten salt & 16 & Molten salt & Hebei & Skyfuel (US)c \& Zhongyang Energy & $(\text { Dec-19) })^{f}$ \\
\hline Lanzhou Dacheng & 50 & Fresnel & Molten salt & 13 & Molten salt & Gansu & Lanzhou Dacheng & Dec-19 \\
\hline Huaneng & 50 & Fresnel & Thermal oil & 6 & Molten salt & Inner Mongolia & Huaneng & Uncleare $^{\mathrm{e}}$ \\
\hline CITIC New Energy & 50 & Fresnel & Water & 14 & Concrete & Hebei & Terasolar & Unclear $^{\mathrm{e}}$ \\
\hline Huaqiang & 50 & Fresnel & Water & 14 & Concrete & Hebei & Terasolar & $(\text { Dec-19) })^{f}$ \\
\hline
\end{tabular}

Sources: (Author's database, 2018; Electric Power Planning \& Engineering Institute, 2018; NEA, 2016); further details in supplementary data. Notes: a) in partnership with Shanghai Electric; b) Originally developed by Guohua; Shouhang later acquired the permit to develop; c) Skyfuel was acquired by Wuhan Kaidi prior to project involvement; d) confirmed operational; e) possibly abandoned, permit to develop may be acquired by other developers; f) dates in brackets are the latest officially announced start dates, but construction is still in an early phase, and the project is likely to miss this start date. 


\section{Origin of system building resources for China's CSP sector}

This section describes the geographic origin of the knowledge, market demand, finance, and legitimacy used in the formation of China's CSP sector, as well as outgoing flows of these resources. A summary overview is provided at the end of this section, in Table 5.

\subsection{Knowledge}

In the pilot project phase, the IEE-CAS and Himin collaboration was one of the stronger domestic forces of knowledge development (see the several projects in Table 2). In these pilot projects, IEE-CAS functioned as the project developer, and was responsible for procurement of equipment and for system integration. Interviewees from both organizations explained that they also co-developed a number of key technologies. For example, the development of a heat-resistant coating for receiver tubes, which was needed to withstand the higher temperatures when using molten salt, was researched simultaneously in a post-doc project at IEE-CAS and in the R\&D department of Himin solar. A similar arrangement was in place for the development of the glass-to-metal bridge (the component connecting the inner steel and outer glass tube of a receiver tube, and preserving the vacuum between them) (interviews \#4, $18,19)$. The Southeast University also worked on a high-temperature receiver tube, developed in collaboration with domestic firms such as Himin, Linuo Paradigma, and IVO (Wang et al., 2017).

Many firms used pilot projects to test self-developed equipment, including a number of firms that were later involved in the 20 utility-scale demonstration projects (Table 2), specifically Lanzhou DCTC, Parasol Energy, Rayspower, Royaltech, SunCan, SupCon, Terasolar, and TRX Solar Tech (details in the supplementary material). Foreign involvement in the pilot projects was relatively limited, with only 6 out of 50 projects having any identifiable foreign support (Table 4). 
Table 4. Foreign involvement in Chinese pilot projects ( $<10 \mathrm{MW}$ )

\begin{tabular}{|c|c|c|c|c|c|}
\hline Developer & Type & Capacity & Location & Year & Foreign involvement \\
\hline Runyang & Tower & $1 \mathrm{MW}$ & Jiangsu & 2014 & $\begin{array}{l}\text { Receiver block technology licensed from } \\
\text { Solastor (Australia) }\end{array}$ \\
\hline Sanhua & Dish & $1 \mathrm{MW}$ & $\begin{array}{l}\text { Inner } \\
\text { Mongolia }\end{array}$ & 2013 & $\begin{array}{l}\text { Sanhua acquired } 31 \% \text { of Helio Focus } \\
\text { (Israel), and has exclusive distribution } \\
\text { rights for the Chinese market for its } \\
\text { technology }\end{array}$ \\
\hline $\begin{array}{l}\text { Datang \& } \\
\text { Tianwei }\end{array}$ & $\begin{array}{l}\text { Trough, } \\
\text { ISCC }\end{array}$ & $\begin{array}{l}1.5 \\
\mathrm{MW}_{\text {th }}\end{array}$ & Gansu & 2013 & $\begin{array}{l}\text { Rioglass (Spain) supplied the reflectors; } \\
\text { SCHOTT Solar (Germany) supplied the } \\
\text { receiver tubes }\end{array}$ \\
\hline Honghai & Dish & $100 \mathrm{~kW}$ & $\begin{array}{l}\text { Inner } \\
\text { Mongolia }\end{array}$ & 2012 & $\begin{array}{l}\text { Cleanergy (Sweden) supplied the sterling } \\
\text { engine }\end{array}$ \\
\hline Sunhome & $\begin{array}{l}\text { Molten } \\
\text { salt } \\
\text { storage }\end{array}$ & $20 \mathrm{MWh}$ & Jiangsu & 2014 & Salt supplied by SQM Solar Salts (Chile) \\
\hline Kangda & Trough & $1 \mathrm{MW}$ & Guangdong & 2013 & $\begin{array}{l}\text { ENEA (Italy) and CENER (Spain) supplied } \\
\text { consulting services }\end{array}$ \\
\hline $\begin{array}{l}44 \text { further pilot } \\
\text { projects }\end{array}$ & Various & $\begin{array}{l}19.3 \\
\text { MW }\end{array}$ & & & $\begin{array}{l}\text { None or not mentioned in available } \\
\text { project documents }\end{array}$ \\
\hline
\end{tabular}

Sources: (Author's database, 2018); further details in supplementary data.

The creation of the firms that built China's first two $10 \mathrm{MW}$ demonstration projects (Table 2) similarly had strong foundations in domestic research institutes and companies.

Representatives of SupCon Solar (interviews \#7, 8) explained that the company was established to utilize the expertise in control systems from its parent company, SupCon. A CSP plant requires control systems for solar tracking and heliostat control systems, salt temperature monitoring and preheater control system, cloud forecasting systems, and systems for the operational control between receiver output, heat exchangers and storage system, and power generation systems. Supcon's 50 MW plant will have circa 100,000 control nodes, a large share of which is used to make sure the plant's 27,000 mirrors reflect sunshine evenly distributed over the entire surface of the central receiver. Overall design and systems integration expertise is provided through consultancy by the Northwest Electric Power Design Institute (NWEPDI), a subsidiary of the Power Construction Corporation of China. Design expertise for the receiver block, heat exchanger and steam generation system comes from Hangzhou Boiler, a founding partner of SupCon Solar, and some consultancy by Zhejiang University. SupCon manufacturers only the control system components, and procures the rest. This required SupCon to engage in co-development with its suppliers for many of its components. The steel and the coating used in the receiver block is imported from US companies, but design and manufacturing is done by Hangzhou Boiler. The team of engineers 
at SupCon comes from universities all over China, with a strong representation from Zhejiang University, which like SupCon, is based in Hangzhou.

The firm involved in the other $10 \mathrm{MW}$ demonstration plant, SunCan, was founded by a post-doc from IEE-CAS, who had both academic experience from his $\mathrm{PhD}$ and post-doc, as well as practical experience from project management for the development of the $1 \mathrm{MW}$ pilot plant by his research group. The founder of SunCan argued that the key competences of his firm were for system integration, and a strong understanding of design specifications of individual components. Procurement of components occurred almost entirely domestically, which required SunCan to supply designs or technical specifications, and perform quality control. Only a limited number of components, specifically the turbine and the molten salt pump, were sourced from leading foreign manufacturers. SunCan has a team of circa 20 engineers, all recruited from domestic institutes (interviews \#5, 6).

A number of leading component manufacturers also strongly relied on domestic sources of knowledge. TRX Solar Tech, a manufacturer of receiver tubes, is a spin-off of the China Academy of Space Technology (CAST), which researches and manufactures satellites. Representatives of the company (interviews \#20-23) explained that the parent firm therefore has strong material science knowledge on the effects of solar radiation and vacuum conditions, both of which are relevant for the manufacture of receiver tubes. TRX developed the absorbent coating for the steel inner tube and the protecting and anti-reflective coatings for the glass outer tube, and designed the manufacturing lines for the assembly of components. The glass tubes are sourced from a local manufacturer, which had to be supported by TRX for mastering their production. The steel-to-glass bridge, a particularly complex component which is used to preserve the vacuum between the steel and glass tubes of the receiver tube, is sourced from the German Witzenmann. Although it thus relies on foreign supplier for one of its most critical components, it is TRX that performs development, assembly and reliability testing of the final product, as well as design and quality control of domestically sourced components.

Himin Solar, another manufacturer of receiver tubes, derived most of its competences from its experience in production of solar water heater systems. Engineers of Himin stressed, however, that although the overall concept of solar water heater and CSP receiver tubes were similar, key differences existed in the absorbent coating, because of the very big temperature differences, and in the glass-to-metal bridge (an SWH receiver is composed entirely of glass, 
with two glass tubes inside each other). Both the coating and the glass-to-metal bridge were developed by Himin itself, with assistance from IEE-CAS (interviews \#18, 19).

There are also examples of more Chinese firms entering the industry with a stronger reliance on foreign knowledge. The founders of Huiyin, a Belgian-Chinese manufacturer of receiver tubes with a substantial global market share, were also involved in the founding of the Israeli Solel company (Hernández Lluna, 2012). The tech supplier of one of China's 20 demonstration projects, Tianjin Binhai, is building a manufacturing base, utilizing technology from Reflex (for reflectors), Archimedes (receiver tubes), and Sarea (tracking equipment) (CSP Plaza, 2016). It is not clear what kind of contractual arrangement is used for this localization. Wuhan Kaidi acquired the US firm Skyfuel, a CSP plant developer and manufacturer of parabolic trough equipment. Shanghai Electric formed a JV with the US firm Brightsource, a CSP plant developer and designer of CSP equipment.

There were also indications of some outgoing flows of knowledge resources. Members of a university based research group developing next generation receiver block technologies indicated that they had relatively more interest from foreign parties than from domestic parties for contract research (interviews \#30, 31). A key reason, the interviewee argued, was that the technologies developed at their lab were tested at large scale, relatively close to market application, compared with foreign research groups. The group's own testing facility for these next generation receiver blocks was a $1 \mathrm{MW}$ tower, comparable to planned facilities recently funded in the Gen3 CSP R\&D program by the U.S. DOE (U.S. DOE, 2018).

\subsection{Market demand}

There had been essentially no domestic market formation in China until the announcement of the 20 demonstration projects in 2016. None of the utility-scale projects planned prior to this policy started construction (CNSTE, 2017b). The two $10 \mathrm{MW}$ tower demonstration projects were constructed when little clarity existed on financial rewards (see also section 4.3) or on future market growth. There had been much industry expectation on the establishment of market creation policies, including a Feed-in Tariff, since the tenders in 2011, but policy had been slow moving since then (CNSTE, 2017b; PV News, 2016)

Component manufacturers interviewed for this article all indicated that they entered the industry with a two-pronged strategy, of focusing on foreign markets, and expecting domestic formation to occur relatively shortly afterwards (interviews $\# 5,7,10,18,19,23,24$ ).

Three manufacturers of receiver tubes and one for steam generation systems indicated that they had managed to sell to commercial scale projects in foreign markets prior 
to the formation of a domestic market (interviews $\# 10,19,24,27$ ). They also indicated that in the current market outlook, the relevance of foreign and domestic markets was of roughly equal weight. The projects included supply of receiver tubes to Germany, France, India and Spain, and steam generator systems to India and Spain.

Two developers, SunCan and SupCon, were both actively looking, and optimistic about their prospects in foreign markets, although they explained that in domestic markets, they were aiming for complete developer roles, whilst in foreign markets they were aiming for more limited roles as solar field EPC contractor at first (interviews \#5, 7). Key markets for these developers were the MENA region and other emerging economy markets. Another developer, Shanghai Electric, already won the contract for EPC services for the DEWA 700 MW CSP plant in Dubai, currently the largest project globally (PR Newswire, 2018). Construction of the solar field has been subcontracted to the Spanish Abengoa, but it may be expected that Shanghai Electric, a manufacturer of power generation and electrical equipment, will be using some of its own products for the remainder of the plant.

Vice versa, although foreign CSP firms have been actively trying to enter the Chinese CSP market (Vieira de Souza and Gilmanova Cavalcante, 2017), results have been rather limited. A number of previous JV or cooperation agreements, typically between foreign tech suppliers and domestic SOE developer companies, have not resulted in much actual project construction (Hu and Wu, 2013). An overview of firms involved in China's 20 demonstration projects is provided in Figure 3 . The component that is most often imported are molten salt pumps, followed by turbines, which have to be able to deal with the variable load typical for CSP plants (interviews \#4, 16, 27). Foreign firms have further been involved mostly in plant design, as owner's engineers, or for component testing (Figure 3; CSP Plaza, 2018a). 


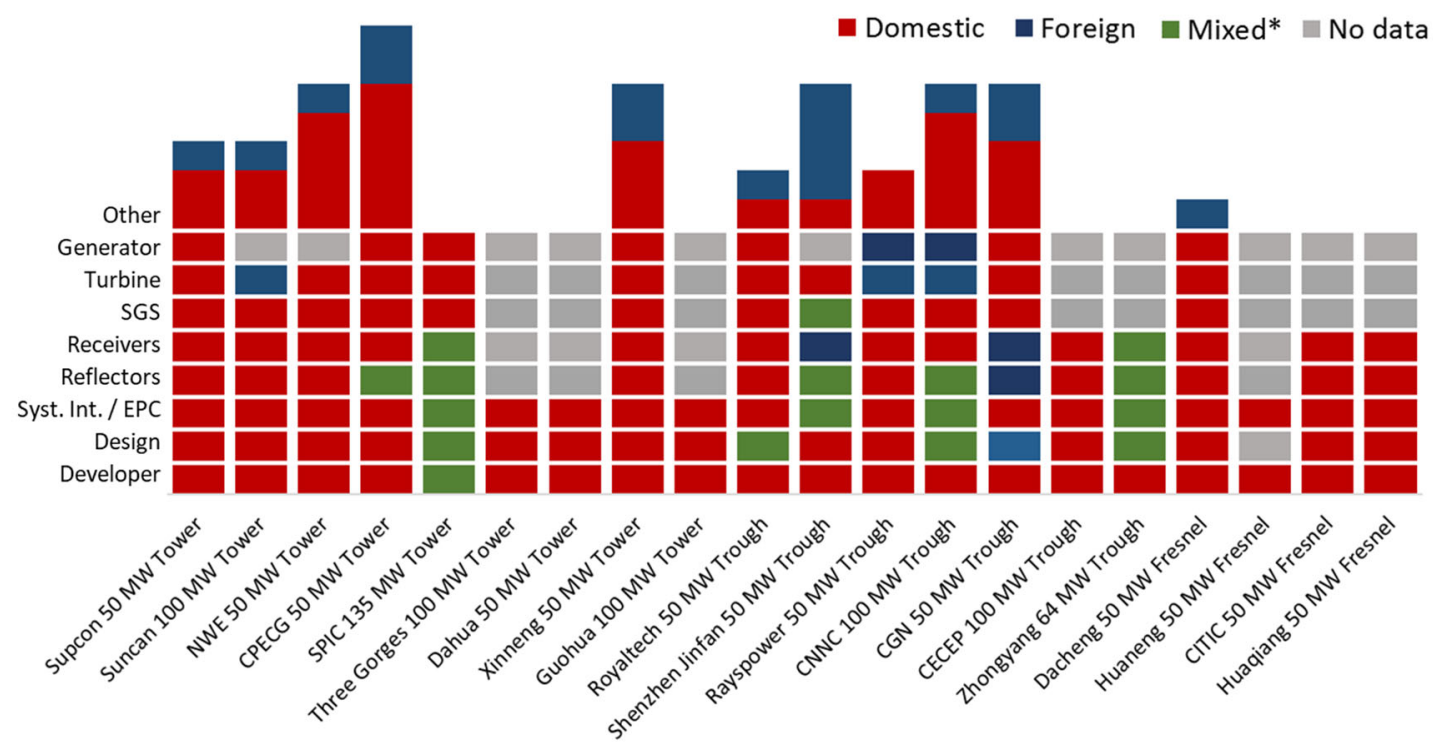

Figure 3. Nationality of firms involved in China's 20 CSP demonstration projects. Notes: Mixed*: either multiple domestic and foreign firms involved, domestic-foreign JV, or a domestic firm using foreign technology. Syst. Int. / EPC: System integration / Engineering, Procurement, and Construction; SGS: Steam Generation System; 'Other': other key components or services, where information was available. Source: (Author's database, 2018), see also the supplementary material.

4.3.

Finance

The pilot projects described in Table 2 were largely financed with research funding from MOST, or by the equipment manufacturers testing their own products (CNSTE, 2013; MOST, 2011). In the pilot projects of IEE-CAS, the level of funding from MOST meant that equipment manufacturers were required to co-sponsor the pilot, by delivering the components at below cost prices (interview \#4).

Investment in SupCon Solar, including for the $10 \mathrm{MW}$ demonstration plant, came from SupCon Group, Hangzhou Boiler, and Hangzhou Turbine (SupCon, 2018). The Feed-in Tariff for the project was awarded in August of 2014, a year after power production started, in an ad hoc decision by the NDRC (CSP Focus, 2018). A SupCon representative explained that the decision to invest was made in order to expand capabilities in large-scale applications of the technology, deemed necessary to compete in the domestic market for commercial sized projects that they expected to be formed soon after. SupCon's founding partners also invested in the $50 \mathrm{MW}$ phase 2 project, with additional finance from a local investment fund (interviews $\# 7,8)$.

Investment in SunCan, and its $10 \mathrm{MW}$ demonstration plant, came from its parent company, ShouHang IHW (65\%), with the remainder invested by a team of private entrepreneurs led by its founder. SunCan, too, decided to start construction prior to the awarding of a Feed-in Tariff. The project started delivering power in 2016, and the NDRC 
decided that $10 \mathrm{MW}$ phase would be covered by the same FiT as the $100 \mathrm{MW}$ second stage, although only after the project as a whole is delivering power to the grid (interview \#5).

CGN Solar's project in Delingha was a lighthouse project for the Chinese market, and required institutional investors and soft interest rates in order to be financially viable. CGN received a $\$ 150$ million loan from the $A D B$, good for $47 \%$ of investment ( $A D B, 2017$ ). Remaining $33 \%$ was invested by the China Import-Export Bank, and $20 \%$ by CGN itself. The rate for the ADB load was the LIBOR rate plus $0.4 \%$, or between 1 and $3 \%$ for the period since it was awarded in 2014, compared to 6 to $8 \%$ interest typically charged by non-institutional investors for the Chinese CSP projects (ADB, 2012). The ADB loan did require the project to use component suppliers with proven track records, resulting in key components sourced from foreign firms (ADB, 2017; see also Figure 3). The World Bank and ADB agreed to cofinance one further project each in 2013, but these were never constructed (IRENA, 2014; World Bank, 2018).

Investment for the other projects listed in Table 3 was all sourced from domestic financiers, although this has been, or remains, a difficulty for many of the projects. SOE developers, that would have the required financing power, are highly risk-averse, whereas private investors have difficulties amassing the required capital of several hundred million dollars. Financing difficulties are the main reason behind delays in these projects (CSP Plaza, 2018b).

Equipment manufacturers interviewed expressed little concern about securing investment for production capacity. Production lines were typically scaled up in small steps at a time, and usually only after supply contracts were signed. The manufacturing base being constructed by Tianjin Binhai, scaled at $200 \mathrm{MW}$ of annual production capacity, required 600 million RMB of investment, and was co-invested in by Shenzhen Nuclear, which does EPC for nuclear power plants, and Binhai High-Tech Zone, a local government agency. None of the interviewed manufacturers were considering an IPO, abroad or at home, to raise capital for such expansion, nor could any news items on such plans be found. The current pace of market growth, however, might not necessitate the large sums of capital as e.g., were raised in the expansion phase by PV manufacturers (Zhang and White, 2016).

There has already been a single, though substantial flow of Chinese finance to assist foreign project development. The DEWA project in Dubai (see also section 4.2) was made possible with a loan of 3.05 billion USD, or $80 \%$ of total project cost, under the flag of the Silk Road fund (Kraemer, 2019). 


\subsection{Legitimacy}

Building legitimacy for the technology and government support still requires substantial effort from local stakeholders. The current primary source of legitimacy for CSP in China is the possibility of integrated energy storage. Large tanks of molten salt or concrete blocks can store thermal energy, which can be used to generate power on demand. This provides a benefit over intermittent PV and wind power sources, which are having much difficulty of being integrated into China's inflexible grid (Du et al., 2018). Policy makers and a researcher advising grid operators indicated the currently preferred design would be plants with as much as 10 hours of thermal storage, which enables CSP plants to charge their storage during the day time, when PV output also peaks, and supply power to the grid only at night. Some plants might even absorb some of the excess daytime PV power in their storage (interviews \#13, 29).

Although China has a strong national-level policy program to support industrial development in high-tech manufacturing sectors, in particular export oriented sectors (Wübbeke et al., 2016), few interviewees agreed such industrial policy was a key driver for stimulus for the CSP sector. Local government support did provide an additional source of legitimacy, with cities in the Western provinces of China, where the CSP plants are being constructed, welcoming the additional economic activity. A number of these cities have awarded development permits on the premise that equipment manufacturing would occur locally, in order to generate high-tech and well-paid labour demand (ESCN, 2018). A number of manufacturers or developers did also indicate that some manufacturing tasks were not too demanding on educational or skills levels, and that the local manufacture of some components, in particular the reflectors and frames, could make sense financially as this would prevent substantial transport costs (interviews \#5, 10).

A remaining barrier in legitimacy formation for the technology is its cost. The current $\mathrm{FiT}$, of 1.15 RMB/kWh, was determined on the basis of it being equal with China's first national FiT for solar PV launched in 2011. The FiT for PV has since been regularly reduced, to between 0.40 and $0.55 \mathrm{RMB} / \mathrm{kWh}$ from July 2019 onwards (NDRC, 2019a). The government stance is that this makes CSP too costly versus other renewables, and a reduction to this FiT is expected for a second batch of demonstration projects. Industry representatives rather argued that the FiT was too low for the CSP industry at the current stage of development, and pointed out that PV demonstration projects prior to 2011 had received FiT as high as $4 \mathrm{RMB} / \mathrm{kWh}$ (interviews \#4, 5). Others argued that 1.15 was quite high for renewable electricity, but more acceptable for RE plus storage. China currently has no power price premiums for peak 
regulating units, an ancillary service that CSP plus storage could provide, although a power market reform is underway (interviews \#25, 29).

In terms of more formalized legitimacy, derived from verification of equipment quality, Chinese equipment manufacturers were still largely dependent on foreign suppliers. Manufacturers sought third party certification to provide reassurances on product quality, and indicated that both foreign and domestic customers asked for certification from foreign agencies, usually the German TÜV or DLR (interviews \#10, 18, 21, 23).

In terms of standard setting, however, China is already contributing to global developments. Global technical standards by the International Electrotechnical Commission are still under development by the IEC Technical Committee TC 117 'Solar thermal electric plants'. Chinese equipment manufacturers and research institutes are well represented in this committee, accounting for circa one third of members in the project teams for standards for e.g., tower or trough equipment (IEC, 2018). Further, China is also actively developing domestic standards, and recently became the first country to implement a design standard for tower type plants (CSP Plaza, 2018c).

Table 5. China's CSP sector and the origin of system building resources

\begin{tabular}{|c|c|c|c|}
\hline Resource & Origin & Supply & Description \\
\hline \multirow[t]{4}{*}{ Knowledge } & Domestically mobilized & ++ & $\begin{array}{l}\text { Strong R\&D activity in local academia and firms, } \\
\text { plentiful pilot activities }\end{array}$ \\
\hline & Sourced from global & $-/+$ & $\begin{array}{l}\text { Small number of instances of firms licensing foreign } \\
\text { tech, or foreign-domestic JVs }\end{array}$ \\
\hline & Contributed towards global & - & $\begin{array}{l}\text { Some domestic research institutes and firms attracting } \\
\text { research contracts foreign firms }\end{array}$ \\
\hline & $\begin{array}{l}\text { Overall effect on domestic } \\
\text { CSP industry formation }\end{array}$ & ++ & $\begin{array}{l}\text { Limited bottlenecks, but expansion phase will require } \\
\text { improved economic efficiency }\end{array}$ \\
\hline \multirow[t]{4}{*}{$\begin{array}{l}\text { Market } \\
\text { demand }\end{array}$} & Domestically mobilized & ++ & $\begin{array}{l}\text { Large market created with the } 20 \text { demonstration } \\
\text { projects, largely captured by domestic firms }\end{array}$ \\
\hline & Sourced from global & $-/+$ & $\begin{array}{l}\text { Initial markets for some equipment manufacturers, } \\
\text { moderately positive outlook in new growth markets }\end{array}$ \\
\hline & Contributed towards global & $-/+$ & $\begin{array}{l}\text { Limited share of Chinese market for design, testing, or } \\
\text { components captured by foreign firms }\end{array}$ \\
\hline & $\begin{array}{l}\text { Overall effect on domestic } \\
\text { CSP industry formation }\end{array}$ & + & $\begin{array}{l}\text { Current largest global market, but lack of clarity on } \\
\text { market support beyond current demonstration projects }\end{array}$ \\
\hline \multirow[t]{4}{*}{ Finance } & Domestically mobilized & $-/+$ & $\begin{array}{l}\text { Bulk of finance is sourced from domestic investors and } \\
\text { balance sheets of developers and manufacturers }\end{array}$ \\
\hline & Sourced from global & - & $\begin{array}{l}\text { One single project with soft loan from ADB. No capital } \\
\text { raised with e.g., listings on foreign exchanges }\end{array}$ \\
\hline & Contributed towards global & $-/+$ & $\begin{array}{l}\text { Project finance for projects in NEMA markets from } \\
\text { Chinese SOE banks, including 'Belt \& Road' funds }\end{array}$ \\
\hline & $\begin{array}{l}\text { Overall effect on domestic } \\
\text { CSP industry formation }\end{array}$ & $-/+$ & $\begin{array}{l}\text { Many projects moving forwards, but finance remains a } \\
\text { hurdle for both private and SOE developers }\end{array}$ \\
\hline Legitimacy & Domestically mobilized & $-/+$ & $\begin{array}{l}\text { Strong interest in non-intermittent renewables, doubts } \\
\text { remain over novelty and cost }\end{array}$ \\
\hline
\end{tabular}




\begin{tabular}{|l|l|l|l|}
\hline & Sourced from global & $-/+$ & Adherence to third-party certification for components \\
\cline { 2 - 5 } & Contributed towards global & + & $\begin{array}{l}\text { Participation in global standard setting committees for } \\
\text { CSP power plants and components }\end{array}$ \\
\cline { 2 - 4 } & $\begin{array}{l}\text { Overall effect on domestic } \\
\text { CSP industry formation }\end{array}$ & $-/+$ & $\begin{array}{l}\text { Policy makers and investors remain hesitant due to high } \\
\text { cost and immaturity vs. PV or wind }\end{array}$ \\
\hline
\end{tabular}

Note: summary of findings reported in section 4. Supply evaluated as: --: very weak; -: weak; -/+: moderate; +: strong; ++: very strong. 


\section{Discussion: China's role in the next phase of the energy transition}

\subsection{Changing relation with global pools of resources for industry formation}

The development of a competent Chinese CSP industry has depended only to a very limited extent on foreign resources for industry formation (Table 5). The development of components and design of complete plants, as well as systems integration capabilities, are largely rooted in domestic research institutes and corporate R\&D. The domestic market has been nearly entirely captured by domestic firms, already in its earliest formative phases, with only limited involvement of foreign knowledge or component suppliers in the construction of China's pilot and demonstration projects. Investment for projects and production capacity nearly uniquely came from domestic government funding (for smaller scale projects), domestic utilities or project developers, equipment manufacturers, and/or domestic banks and other financiers. Domestic actors have engaged in activities to mobilize legitimacy for the novel technology, including by drafting design standards, by arguing that CSP has a utility and value exceeding that of other forms of (variable) renewable electricity because of its possibilities for cheap thermal storage and $24 \mathrm{~h}$ dispatchability, that its costs will come down in the future, and that it has economic development benefits for China's inland regions, where much of the projects are located.

Vice versa, the relatively recently formed Chinese CSP industry has already started to contribute to industry formation processes outside of the Chinese context (Table 5). Domestic research institutes and firms have attracted research contracts from foreign entities, including for testing and developing next-generation receiver technologies in demonstration-scale projects. Chinese banks, under the flag of the Silk Road fund, have provided substantial amounts of investment to the development of foreign projects, with the stated aim of assisting domestic firms export success. A number of Chinese EPC and equipment manufacturing firms have also managed to find demand in foreign markets, even though the recent establishment of a domestic market meant these firms had limited or no domestic project references. Lastly, Chinese firms and research institutes are contributing experience and understanding of the technologies towards defining global project design and equipment standards, helping set quality benchmarks for firms from other countries to work towards.

This development pattern is strikingly different from what has previously been observed in other renewable energy sectors in China (and other emerging economies), where inputs of foreign technology, market demand, finance, and/or legitimacy were of decisive importance for early industry development, with outgoing flows of such resources for industry 
formation developing only after substantial maturation of the domestic sector (Binz and Anadon, 2018; Fang and Li, 2013; Gosens and Lu, 2013; Lewis, 2007; Quitzow, 2015).

This suggests that China, in the development of next-generation renewable energy technologies that may come to flourish in the next phase of the global energy transition, may no longer be limited to the role of a follower country that manages to outcompete advanced economies in equipment manufacturing only after substantial technological maturation (Abernathy and Clark, 1985; Nahm and Steinfeld, 2014). Rather, China may very well be a much more central player in the early stage development of these technologies and their corresponding industries.

\subsection{A new niche development environment}

China's role in the next phase of the global energy transition, however, may not be limited to it being a less dependent on, and more contributing to, global industry formation processes. Perhaps more importantly, the Chinese domestic environment for industrial path development has a number of features that distinguishes it from those seen in most OECD countries (cf. Altenburg et al., 2016), and that may affect the industrial path development trajectories that are possible.

First, China's size and growing level of capabilities mean it has an increasingly suitable environment for recombination of previously unrelated knowledge bases. A CSP plant, for example, requires competencies in electrical engineering, material sciences, information and control technologies, etc., and Chinese project developers indicated limited difficulties with finding the required skills for plant design, nor with finding competent suppliers of components as diverse as steel and glass tubing, anti-reflective and absorptive coatings, specialty mirrors, control systems, and more. Although China is not entirely unique in this respect, there are few countries that have such diverse and capable manufacturing industries as China (Nahm and Steinfeld, 2014).

Second, China's large government budget allows for very substantial expenditure on support policies. The Chinese demonstration program, with 20 projects and a total capacity of 1,350 MW, was the largest volume of projects introduced in a single policy measure so far, representing almost $30 \%$ of the global cumulative installations (ca. 4,700 MW and 75 projects) at the time of its launch. Further, compared with the stop-and-go support for CSP and other renewables in the US and Spain (Hu and Wu, 2013; Martin, 2016), Chinese support policy for wind and PV has been much more stable, with reductions in FiT, and an eventual sunset date, communicated well in advance (e.g., NDRC, 2019b). It is not certain that this will be replicated 
in the CSP sector, however, as there has, so far, not been a clear decision on a second round of demonstration projects, nor on a generally applicable FiT for future CSP projects.

Third, the Chinese government has shown a willingness to experiment with different technologies. The CSP demonstration program allowed only a single plant of each overall design (trough, tower, Fresnel, dish) in any single province, and selected roughly half private and half SOE developer companies, with the purpose of optimal configuration for project development (interviews \#4, 15, 25, 26). Governments in most other countries tend to be hesitant to pick winning technologies, and rather leave such choices the market (Mazzucato, 2015). As investors are usually risk-averse, they tend to select projects utilizing technologies with the best track record which, in the CSP sector, has led to a concentration of investment in thermal oil-based parabolic trough projects (interviews \#5, 23, 24; see also section 3.2). By explicitly selecting projects with a number of different technologies, the Chinese government negated the lock-in to that single technological trajectory, and opened up potentially superior or complementary CSP trajectories.

Lastly, entrepreneurial risk adversity in the Chinese CSP sector appears to be lower than in most countries as well, with the construction of the two $10 \mathrm{MW}$ demonstration projects being the clearest example. These projects each required investment of several dozen million USD, yet construction was finished prior to an FiT being awarded (section 4.3). This 10 MW scale is in between pilot and commercial demonstration scale, which is the development stage that is regularly associated with the 'valley of death', where investment exceeds the capabilities of academic funds or angel investors, whilst performance of the technology remains too uncertain for corporate investors with larger access to capital (Auerswald and Branscomb, 2003; Barr et al., 2014). Further, the 20 projects in the demonstration program included 9 towers using molten salt, whilst only 2 such projects were operational at the time, globally, and further included parabolic trough and Fresnel type projects using molten salt, which would be global firsts. The Fresnel project is nearing completion, and expected to be operational by the end of 2019, whilst the molten salt parabolic trough projects are delayed with unclear end dates, quite possibly because of difficulties securing finance (CSP Focus, 2019; CSP Plaza, 2018b).

These particular characteristics of the Chinese domestic environment for industrial path development may mean that China, in the next phase of the global energy transition, may help open up industrial path development trajectories that are unlikely to form in most OECD countries. This may help broaden the set of technologies available for decarbonization of the energy system, and thereby accelerate global energy transitions. 


\section{Conclusion}

The formation of a competent CSP sector in China, although a recent and ongoing phenomenon, has largely depended on domestic resources for industry formation. Development of components and design of complete plants, as well as systems integration capabilities, are largely rooted in domestic research institutes and corporate R\&D. The developers, component suppliers, and financiers for projects in the domestic market are largely domestic actors. Rather than taking cues from established global quality standards, Chinese entities are actively involved in co-developing these. This development pattern is strikingly different from what has previously been observed in other renewable energy sectors in China and other emerging economies, where inputs of foreign technology and foreign market demand were of decisive importance for sector development.

Further, the Chinese environment for industrial path development has a number of features that distinguishes it from those seen in most OECD countries. Policy makers are more willing to interfere in technological selection and experimentation processes, and are highly trusted in their ability to deliver long-term and stable support measures. Simultaneously, there are large numbers of entrepreneurs that are willing to work on product development and co-create market demand and institutional support prior to the establishment of formal policy strategies. Lastly, investors are willing to fund multi-million dollar demonstration projects on the perceived returns from highly uncertain future markets, indicating levels of risk acceptance that far exceed Western standards (cf. Gosens et al., 2018; Tyfield, 2018; Tyfield et al., 2015).

This suggests that China may be a much more central player in the early stage development of next-generation renewable energy technologies and their corresponding industries. The addition of China as an independent and distinct environment for industrial path development may further mean that China may help open up industrial path development trajectories that are unlikely to form in most OECD countries. This may help broaden the set of technologies available for decarbonization of the energy system, and thereby accelerate global energy transitions. Discussions on the next phase of the global energy transition should arguably include attention to such shifting geographical patterns in the development of next-generation renewables. 


\section{Acknowledgement}

This research was supported by Aalborg University (AAU Grant 771107) and a travel grant from the Sino-Danish Center for Education and Research (SDC). These financiers had no involvement in research design or reporting.

\section{Author contributions}

Jorrit Gosens: Conceptualization, Investigation, Data Curation, Visualization, Funding acquisition (field work grant), Writing - Original Draft, Writing - Review \& Editing; Christian Binz: Conceptualization, Writing - Review \& Editing; Rasmus Lema: Funding acquisition, Writing - Review \& Editing. 


\section{References}

Abernathy, W.J., Clark, K.B., 1985. Innovation: Mapping the winds of creative destruction. Res. Policy 14, 3-22.

Abramovitz, M., 1986. Catching Up, Forging Ahead, and Falling Behind. J. Econ. Hist. 46, 385486.

ADB, 2017. China, People's Republic of: Qinghai Delingha Concentrated Solar Thermal Power Project. Sovereign (Public) Project 46058-002.

ADB, 2012. People's Republic of China: Concentrating Solar Thermal Power Development. Project Number: 43356 / TA 7402.

Altenburg, T., Sagar, A., Schmitz, H., Xue, L., 2016. Guest editorial: Comparing low-carbon innovation paths in Asia and Europe. Sci. Public Policy 43, 451-453.

Andersson, J., Hellsmark, H., Sandén, B.A., 2018. Shaping factors in the emergence of technological innovations: The case of tidal kite technology. Technol. Forecast. Soc. Change 132, 191-208. https://doi.org/10.1016/J.TECHFORE.2018.01.034

Auerswald, P.E., Branscomb, L.M., 2003. Valleys of Death and Darwinian Seas: Financing the Invention to Innovation Transition in the United States. J. Technol. Transf. 28, 227-239. https://doi.org/10.1023/A:1024980525678

Author's database, 2018. Project database collecting information from industry news sites such as CSP focus, CSP Plaza, CNSTE, and company websites. Summary data included as supplementary material.

Barr, S.H., Baker, T., Markham, S.K., Kingon, A.L., 2014. Bridging the valley of death: lessons learned from 14 years of commercialization of technology education. Eng. Manag. Rev. IEEE 42, 13-34. https://doi.org/10.1109/EMR.2014.6758259

Binz, C., Anadon, L.D., 2018. Unrelated diversification in latecomer contexts-The emergence of the Chinese solar photovoltaics industry. Environ. Innov. Soc. Transitions. https://doi.org/10.1016/J.EIST.2018.03.005

Binz, C., Truffer, B., 2017. Global Innovation Systems-A conceptual framework for innovation dynamics in transnational contexts. Res. Policy 46, 1284-1298. https://doi.org/10.1016/j.respol.2017.05.012

Binz, C., Truffer, B., Coenen, L., 2016. Path Creation as a Process of Resource Alignment and Anchoring: Industry Formation for On-Site Water Recycling in Beijing. Econ. Geogr. 92, 172-200.

BLM, 2004. Solar plant California, US Bureau of land management.

Chaanaoui, M., Vaudreuil, S., Bounahmidi, T., 2016. Benchmark of Concentrating Solar Power Plants: Historical, Current and Future Technical and Economic Development. Procedia Comput. Sci. 83, 782-789. https://doi.org/https://doi.org/10.1016/j.procs.2016.04.167

CNSTE, 2017a. A 50MW beam-down molten salt tower plant started BOP Construction [WWW Document]. URL http://en.cnste.org/html/events/2017/0904/307.html

CNSTE, 2017b. Blue Book for Industry Development of Chinese Concentrated Solar Power and Solar Heating in 2016.

CNSTE, 2013. Research Report on China's Solar Thermal Power Generation Industry Policy [In Chinese].

Coventry, J., Andraka, C., 2017. Dish systems for CSP. Sol. Energy 152, 140-170. https://doi.org/10.1016/J.SOLENER.2017.02.056

CSP Focus, 2019. 6 CSP solar projects with 350MW capacity will be newly built in China this year [WWW Document]. URL http://www.cspfocus.cn/en/market/detail_2004.htm (accessed 9.19.19).

CSP Focus, 2018. SupCon Delingha 10MW Tower CSP Project [WWW Document]. URL http://www.cspfocus.cn/study/pdetail_208.htm (accessed 5.14.18).

CSP Plaza, 2018a. CSP Plaza introduction [WWW Document]. URL http://en.cspplaza.com/download/CSPPLAZA INTRODUCTION.pdf (accessed 7.26.18).

CSP Plaza, 2018b. Progress between different CSP projects has started to diverge in past two months (In Chinese) [WWW Document]. URL http://www.cspplaza.com/article-8315-1.html

CSP Plaza, 2018c. The World's First Tower-Type CSP Design Standard Officially Released [WWW Document]. URL http://en.cspplaza.com/the-worlds-first-tower-type-csp-design-standardofficially-released/ (accessed 11.20.18).

CSP Plaza, 2016. The first batch of 20 CSP demonstration projects [WWW Document]. URL 
http://www.cspplaza.com/article-8085-1.html (accessed 5.12.18).

CSP Plaza, 2015. 2014 Statistics on China's CSP projects that have finished construction and are operational [In Chinese] [WWW Document]. URL http://www.cspplaza.com/article-4516-1.html

de la Tour, A., Glachant, M., Ménière, Y., 2011. Innovation and international technology transfer: The case of the Chinese photovoltaic industry. Energy Policy 39, 761-770. https://doi.org/10.1016/j.enpol.2010.10.050

Du, E., Zhang, N., Hodge, B.-M., Kang, C., Kroposki, B., Xia, Q., 2018. Economic justification of concentrating solar power in high renewable energy penetrated power systems. Appl. Energy $222,649-661$.

EC, 2018. Solar energy - Summary of raodmaps - SETIS - Strategic Energy Technologies Infromation System [WWW Document]. URL https://setis.ec.europa.eu/summary-of-roadmaps (accessed 8.10.18).

Electric Power Planning \& Engineering Institute, 2018. Progress of first batch of demonstration projects [WWW Document]. URL http://www.cspfocus.cn/market/detail_640.htm (accessed 5.3.18).

Ernst, D., Kim, L., 2002. Global production networks, knowledge diffusion, and local capability formation. Res. Policy 31, 1417 1429. https://doi.org/10.1016/s0048-7333(02)00072-0

ESCN, 2018. Rayspower and Yumen city sig contract for $100 \mathrm{MW}$ CSP project and manufacturing base [WWW Document]. URL http://www.cspplaza.com/article-4615-3.html (accessed 10.18.19).

Fang, X., Li, D., 2013. Solar photovoltaic and thermal technology and applications in China. Renew. Sustain. Energy Rev. 23, 330-340. https://doi.org/http://dx.doi.org/10.1016/j.rser.2013.03.010

$\mathrm{Fu}, \mathrm{X}$., Zhang, J., 2011. Technology transfer, indigenous innovation and leapfrogging in green technology: the solar-PV industry in China and India. J. Chinese Econ. Bus. Stud. 9, 329-347.

Gereffi, G., Humphrey, J., Sturgeon, T., 2005. The governance of global value chains. Rev. Int. Polit. Econ. 12, 78 104. https://doi.org/10.1080/09692290500049805

Gerschenkron, A., 1962. Economic backwardness in historical perspective: a book of essays. Belknap Press of Harvard University Press Cambridge, MA.

Glasspoint Solar, 2014. Enclosed trough [WWW Document]. URL http://www.glasspoint.com/resources/press-kit/\%0A (accessed 3.4.19).

Gosens, J., Hellsmark, H., Kåberger, T., Liu, L., Sandén, B.A., Wang, S., Zhao, L., 2018. The limits of academic entrepreneurship: Conflicting expectations about commercialization and innovation in China's nascent sector for advanced bio-energy technologies. Energy Res. Soc. Sci. 37. https://doi.org/10.1016/j.erss.2017.09.014

Gosens, J., Lu, Y., 2013. From lagging to leading? Technological innovation systems in emerging economies and the case of Chinese wind power. Energy Policy 60, 234-250. https://doi.org/10.1016/j.enpol.2013.05.027

Gosens, J., Lu, Y., Coenen, L., 2015. The role of transnational dimensions in emerging economy 'Technological Innovation Systems' for clean-tech. J. Clean. Prod. 86, 378-388. https://doi.org/10.1016/j.jclepro.2014.08.029

Hansen, U.E., Nygaard, I., 2013. Transnational linkages and sustainable transitions in emerging countries: Exploring the role of donor interventions in niche development. Environ. Innov. Soc. Transitions 8, 1-19. https://doi.org/http://dx.doi.org/10.1016/j.eist.2013.07.001

Hernández Lluna, C., 2012. Solar thermal electricity in china in 2011 and future outlook. Report for the European Solar Thermal Electricity Association.

Hu, M.-C., Wu, C.-Y., 2013. Concentrating Solar Power - China's New Solar Frontier. Asia-Pacific J. 11, $1-11$.

Hussain, A., Arif, S.M., Aslam, M., 2017. Emerging renewable and sustainable energy technologies: State of the art. Renew. Sustain. Energy Rev. 71, 12-28.

IEC, 2018. TC 117 Solar thermal electric plants [WWW Document]. URL https://www.iec.ch/tc117 (accessed 11.20.18).

IRENA, 2014. Renewable Energy Prospects: China.

Kraemer, S., 2019. China to Finance and Shanghai Electric to Build CSP for ACWA Power's 950MW Dubai Solar Plant [WWW Document]. URL https://www.solarpaces.org/china-to-finance-andshanghai-electric-to-build-csp-for-acwa-powers-950mw-dubai-solar-plant/ (accessed 9.24.19).

Laird, J., 2012. Still on track? Renew. Energy Focus 13, 54-59. https://doi.org/10.1016/S17550084(12)70042-X

Lema, R., Lema, A., 2012. Technology transfer? The rise of China and India in green technology 
sectors. Innov. Dev. 2, 23 44. https://doi.org/10.1080/2157930x.2012.667206

Lewis, J.I., 2010. The evolving role of carbon finance in promoting renewable energy development in China. Energy Policy 38, 2875-2886.

https://doi.org/http://dx.doi.org/10.1016/j.enpol.2010.01.020

Lewis, J.I., 2007. Technology acquisition and innovation in the developing world: Wind turbine development in China and India. Stud. Comp. Int. Dev. 42, 208232. https://doi.org/10.1007/s12116-007-9012-6

Lilliestam, J., Barradi, T., Caldés, N., Gomez, M., Hanger, S., Kern, J., Komendantova, N., Mehos, M., Hong, W.M., Wang, Z., Patt, A., 2018. Policies to keep and expand the option of concentrating solar power for dispatchable renewable electricity. Energy Policy 116, 193-197. https://doi.org/https://doi.org/10.1016/j.enpol.2018.02.014

Lilliestam, J., Labordena, M., Patt, A., Pfenninger, S., 2017. Empirically observed learning rates for concentrating solar power and their responses to regime change (with database update of 2018-05-14 from csp.guru/data.html). Nat. Energy 2, 17094.

Lundvall, B.-A., 1992. National systems of innovation: Towards a theory of innovation and interactive learning. Pinter Publishers, London.

Malerba, F., Nelson, R., 2011. Learning and catching up in different sectoral systems: evidence from six industries. Ind. Corp. Chang. 20, 1645-1675. https://doi.org/10.1093/icc/dtr062

Markard, J., 2018. The next phase of the energy transition and its implications for research and policy. Nat. Energy 1.

Martin, R., 2016. Ivanpah's Problems Could Signal the End of Concentrated Solar in the U.S., MIT Technology Review.

Mathews, J.A., 2006. Catch-up strategies and the latecomer effect in industrial development. New Polit. Econ. 11, 313-335. https://doi.org/10.1080/13563460600840142

Mathews, J.A., 2002. Competitive Advantages of the Latecomer Firm: A Resource-Based Account of Industrial Catch-Up Strategies. Asia Pacific J. Manag. 19, 467-488. https://doi.org/10.1023/A:1020586223665

Mazzucato, M., 2015. The entrepreneurial state: Debunking public vs. private sector myths. Anthem Press.

MOST, 2011. Thermal load test of Yanqing Experimental solar thermal power generation station was successful [In Chinese] [WWW Document]. URL http://www.most.gov.cn/kjbgz/201108/t20110803_88779.htm (accessed 5.3.18).

Nahm, J., Steinfeld, E.S., 2014. Scale-up Nation: China's Specialization in Innovative Manufacturing. World Dev. 54, 288-300. https://doi.org/10.1016/j.worlddev.2013.09.003

NDRC, 2019a. Circular on improving the Feed-in Tariff mechanism for PV power generation.

NDRC, 2019b. Notice on improving the wind power Feed-in tariff policy [WWW Document].

NEA, 2016. Circular on the construction of solar thermal power generation demonstration projects (English translation) [WWW Document]. URL https://chinaenergyportal.org/en/circularconstruction-solar-thermal-power-generation-demonstration-projects/ (accessed 5.3.18).

Perez, C., Soete, L., 1988. Catching up in technology: entry barriers and windows of opportunity, in: Dosi, G., Freeman, C., Nelson, R., Silverberg, G., Soete, L (Eds.), Technical Change and Economic Theory. Columbia University Press and Pinter, London and New York.

Philibert, C., 2014. Technology roadmap: solar thermal electricity-2014 edition. IEA, Paris, Fr.

PR Newswire, 2018. EPC Contract with Shanghai Electric to Develop 700 MW DEWA CSP Project Signed in China [WWW Document]. URL https://www.prnewswire.com/news-releases/epccontract-with-shanghai-electric-to-develop-700-mw-dewa-csp-project-signed-in-china679802743.html (accessed 5.9.18).

PV News, 2016. The Delingha project is scheduled to go into operation in 2016. Can PV be replaced by CSP? [In Chinese] [WWW Document]. URL http://www.pvnews.cn/chanyepinglun/2016-0104/134791.html (accessed 5.8.18).

Quitzow, R., 2015. Dynamics of a policy-driven market: The co-evolution of technological innovation systems for solar photovoltaics in China and Germany. Environ. Innov. Soc. Transitions 17, 126148.

Sandia National Laboratories, 2018. Solar Power Tower, PIX 00036.

Schmidt, T.S., Huenteler, J., 2016. Anticipating industry localization effects of clean technology deployment policies in developing countries. Glob. Environ. Chang. 38, 8-20.

Sengers, F., Raven, R., 2015. Toward a spatial perspective on niche development: The case of Bus 
Rapid Transit. Environ. Innov. Soc. Transitions 17, 166-182.

https://doi.org/10.1016/J.EIST.2014.12.003

Shin, J.-S., 1996. The Economics of the Latecomers: Catching-up, technology transfer and institutions in Germany, Japan and South Korea, Edition of. ed. Routledge, London.

Smil, V., 2016. Examining energy transitions: A dozen insights based on performance. Energy Res. Soc. Sci. 22, 194-197.

Smith, A., Ely, A., 2015. Green transformations from below? The politics of grassroots innovation, in: The Politics of Green Transformations. Routledge, pp. 120-136.

SolarPACES/NREL, 2018. SolarPACES Concentrating Solar Power Projects Database.

SupCon, 2018. SupCon solar: Background [WWW Document]. URL http://www.supconsolar.com/en/about.asp?id=13 (accessed 5.16.18).

Teddlie, C., Yu, F., 2007. Mixed methods sampling: A typology with examples. J. Mix. Methods Res. 1, 77-100.

Tyfield, D., 2018. Innovating innovation-Disruptive innovation in China and the low-carbon transition of capitalism. Energy Res. Soc. Sci. 37, 266-274. https://doi.org/10.1016/j.erss.2017.10.024

Tyfield, D., Ely, A., Geall, S., 2015. Low carbon innovation in China: from overlooked opportunities and challenges to transitions in power relations and practices. Sustain. Dev. 23, 206-216.

U.S. DOE, 2018. Generation 3 Concentrating Solar Power Systems (Gen3 CSP) funding program [WWW Document]. URL https://www.energy.gov/eere/solar/generation-3-concentrating-solar-powersystems-gen3-csp (accessed 8.10.18).

Vieira de Souza, L.E., Gilmanova Cavalcante, A.M., 2017. Concentrated Solar Power deployment in emerging economies: The cases of China and Brazil. Renew. Sustain. Energy Rev. 72, 1094-1103. https://doi.org/10.1016/J.RSER.2016.10.027

Villarini, M., Limiti, M., Abenavoli, R.I., 2011. Overview and comparison of global concentrating solar power incentives schemes by means of computational models, in: International Conference on Computational Science and Its Applications. Springer, pp. 258-269.

Wang, J., Yang, S., Jiang, C., Zhang, Y., Lund, P.D., 2017. Status and future strategies for Concentrating Solar Power in China. Energy Sci. Eng. 5, 100-109. https://doi.org/10.1002/ese3.154

Wieczorek, A.J., Hekkert, M.P., Coenen, L., Harmsen, R., 2015a. Broadening the national focus in technological innovation system analysis: The case of offshore wind. Environ. Innov. Soc. Transitions 14, 128-148. https://doi.org/https://doi.org/10.1016/j.eist.2014.09.001

Wieczorek, A.J., Raven, R., Berkhout, F., 2015b. Transnational linkages in sustainability experiments: A typology and the case of solar photovoltaic energy in India. Environ. Innov. Soc. Transitions 17, 149-165. https://doi.org/https://doi.org/10.1016/j.eist.2015.01.001

World Bank, 2018. World Bank Projects and operations database: Concentrated Solar Power [WWW Document]. URL http://projects.worldbank.org/search?lang=en\&searchTerm=concentrated solar (accessed 5.13.18).

Wübbeke, J., Meissner, M., Zenglein, M.J., Ives, J., Conrad, B., 2016. Made in China 2025. Mercat. Inst. China Stud. 2, 14-41.

Yap, X.-S., Truffer, B., 2019. Shaping selection environments for industrial catch-up and sustainability transitions: A systemic perspective on endogenizing windows of opportunity. Res. Policy 48, 1030-1047.

Yap, X.-S., Truffer, B., Li, D., Heimeriks, G., 2019. From knowledge-based to valuation oriented catching-up China's recent shift in global positioning in the solar PV industry. Paper presented at the EU-SPRI conference, June 5-7, Rome, Italy.

Zhang, W., White, S., 2016. Overcoming the liability of newness: Entrepreneurial action and the emergence of China's private solar photovoltaic firms. Res. Policy 45, 604-617. 


\section{Appendix A. List of interviewees}

\begin{tabular}{|c|c|c|}
\hline$\#$ & Organization & Role \\
\hline 2 & Chinese Academy of Sciences & Professor \& CSP project manager \\
\hline 3 & China National Renewable Energy Centre & Deputy director; Senior industry analyst \\
\hline 4 & CSP industry association & Secretary General \\
\hline 6 & Developer \& Equipment manufacturer: SunCan & Technical manager \\
\hline 7 & Developer \& Equipment manufacturer: SupCon & Vice Chief engineer \\
\hline 8 & Developer \& Equipment manufacturer: SupCon & Technology management officer \\
\hline 12 & Developer F & Project manager \\
\hline 13 & Energy Research Institute of the NDRC & Assoc. Research Fellow \\
\hline 14 & Energy Research Institute of the NDRC & Deputy director; Assoc. Research Fellow \\
\hline 15 & Foreign equipment manufacturer & General manager \\
\hline 16 & Foreign tech supplier & Project and Engineering Director \\
\hline 17 & North China Electric Power University & Professor \& CSP project manager \\
\hline 23 & Receiver tube manufacturer: TRX & Foreign business manager \\
\hline 24 & Receiver tube manufacturer $\mathrm{C}$ & Global Director of Sales \\
\hline 25 & Renewable energy industry association & Deputy Secretary General \\
\hline 26 & Renewable energy industry association & Director, policy research \\
\hline 27 & Steam Generation System manufacturer A & President \\
\hline 28 & Technology provider \& consulting agency & CEO \\
\hline 29 & Tsinghua University & Assoc. Prof., Electrical Engineering Dept. \\
\hline 30 & Zhejiang university & Prof., Institute for Thermal Power Engineering \\
\hline 31 & Zhejiang university & $\begin{array}{l}\text { Post-doc, Institute for Thermal Power } \\
\text { Engineering }\end{array}$ \\
\hline
\end{tabular}

Note: organizations indicated with letters to respect requests for anonymity of interviewees. 